\title{
VASCULAR CHANGES AT SITES OF OESTROGEN BIOSYNTHESIS PRODUCED BY PARENTERAL INJECTION OF CADMIUM SALTS: THE DESTRUCTION OF PLACENTA BY CADMIUM SALTS
}

\author{
J. PǍ̌́IZEK
}

Institute of Physiology, Department of Physiologv and Pathophysiology of Metabolism, Czechoslovak Academy of Sciences, Salmovská 1, Prague 2, Czechoslovakia

(Received 3rd December 1963)

Oedema, hyperaemia, haemorrhage and vascular thrombosis are constant components of changes in male gonads evoked by subcutaneous or intraperitoneal injection of cadmium salts, which result in complete testicular necrosis (Pař́zek \& Záhoř, 1956; Pařizek, 1957, 1960). In the pathogenesis of testicular necrosis caused by cadmium salts, there are two possibilities (Pařízek, 1960).

(a) Either cadmium salts evoke circulatory failure in the testis, resulting in secondary destruction of the tubules, or

(b) These circulatory changes are sequelae of primary tubular damage.

In the former case, it remains to explain the organ specificity of these severe circulatory changes, although the role of circulatory changes in the pathogenesis of testicular necrosis produced by cadmium has been underlined by several recent authors (cf. Mason, Brown \& Nesbit, I963; Chiquoine, 1963).

At least one of the substances produced by the testis, oestrogen, has a clear relationship to circulation, chiefly capillary. We therefore posed the question whether specific circulatory changes in the testis following parenteral administration of cadmium ions, namely oedema, hyperaemia and later haemorrhage, are related to the production of oestrogens in the testis. If such were the case, one would expect parenteral administration of cadmium to produce circulatory changes, analogous to those seen in the testis, at all other known sites of oestrogen production, including the placenta, ovaries and adrenal glands. A preliminary report of experimental evidence in support of this hypothesis has appeared elsewhere (Pařizek, 1963). This communication is confined to reporting the effects of cadmium cations upon the placenta.

Cadmium cations, in the form of cadmium chloride, acetate or lactate, were given to pregnant rats (Wistar substrain Konárovice; kept on a standard laboratory diet) in a dose of $0.04 \mathrm{~m}$-mole $/ \mathrm{kg}$ body weight (cf. Pařízek, 1957). A $0.02 \mathrm{M}$ solution of cadmium salt in saline was injected subcutaneously, between the scapulae, into seventy pregnant rats between the 17 th and 21 st day of 
gestation. A further group of twelve rats served as controls given no injection, or an equimolar amount of mercury cations (as the chloride).

Subcutaneous injection of cadmium salts was followed in all cases by rapidly progressive placental changes, chiefly in the pars foetalis, which was completely transformed within $24 \mathrm{hr}$ into an extensive blood clot with little remaining necrotic tissue (Plate 1). Only slight changes were found in the pars materna of the placenta, slight oedema and hyperaemia. In the majority of cases the placental changes were accompanied by haemorrhage into the uterine cavity, even by external bleeding. These changes could often be found within $6 \mathrm{hr}$ after cadmium injection. Complete destruction of the pars foetalis resulted in the interruption of pregnancy, with either delivery of the dead conceptus or resorption.

In these experiments the possibility of a further direct action of cadmium cations on the foetus was not excluded. In preliminary experiments, however, even when foetuses were removed surgically just at the time of cadmium administration, damage was detectable in the placenta which remained in situ in the uterus.

Analagous placental damage was evoked by each of the cadmium salts used, the chloride, acetate and lactate. In contrast, following injection of an equimolar amount of mercuric chloride, no comparable changes in the pars foetalis could be detected even after $24 \mathrm{hr}$. Placental destruction, therefore, appeared to be specific to cadmium cations.

It thus appears that cadmium cations cause selective circulatory damage not only in the testes, but in other oestrogen-producing organs. (See Pařizek, 1963, for evidence concerning other places of oestrogen production.)

The question remains as to the cause of this localization of severe vascular changes, evoked by cadmium, at sites of oestrogen biosynthesis. Even if one cannot yet exclude the possibility that this is fortuitous, and that the common denominator linking these effects in these organs lies in some common characteristic other than oestrogen production, we consider the hypothesis attractive. It is being used as the basis for further research, and its potential usefulness in the destruction of, for example, oestrogen-producing tumors is being borne in mind. Destruction of the placenta and interruption of pregnancy by means of small doses of cadmium opens further perspectives: the effect of cadmium ions on the testis can be prevented by simultaneous administration of an excess of zinc cations (Paŕizek, 1956, 1957), and it remains to be seen if this antagonism also operates in the case of the placenta. This of course brings to the fore the entire question of the possible significance of trace metals, physiological as well as toxic, in placental function and in the physiology and pathology of pregnancy. It seems to be necessary to mention in this connexion the well-known parallel effect of vitamin $\mathbf{E}$ deficiency in the testis and placenta.

I should like to express my thanks to Mr J. Fiala for the preparation of photomicrographs and to Mr K. Krejčí for technical assistance. 


\section{PLA'TE 1}

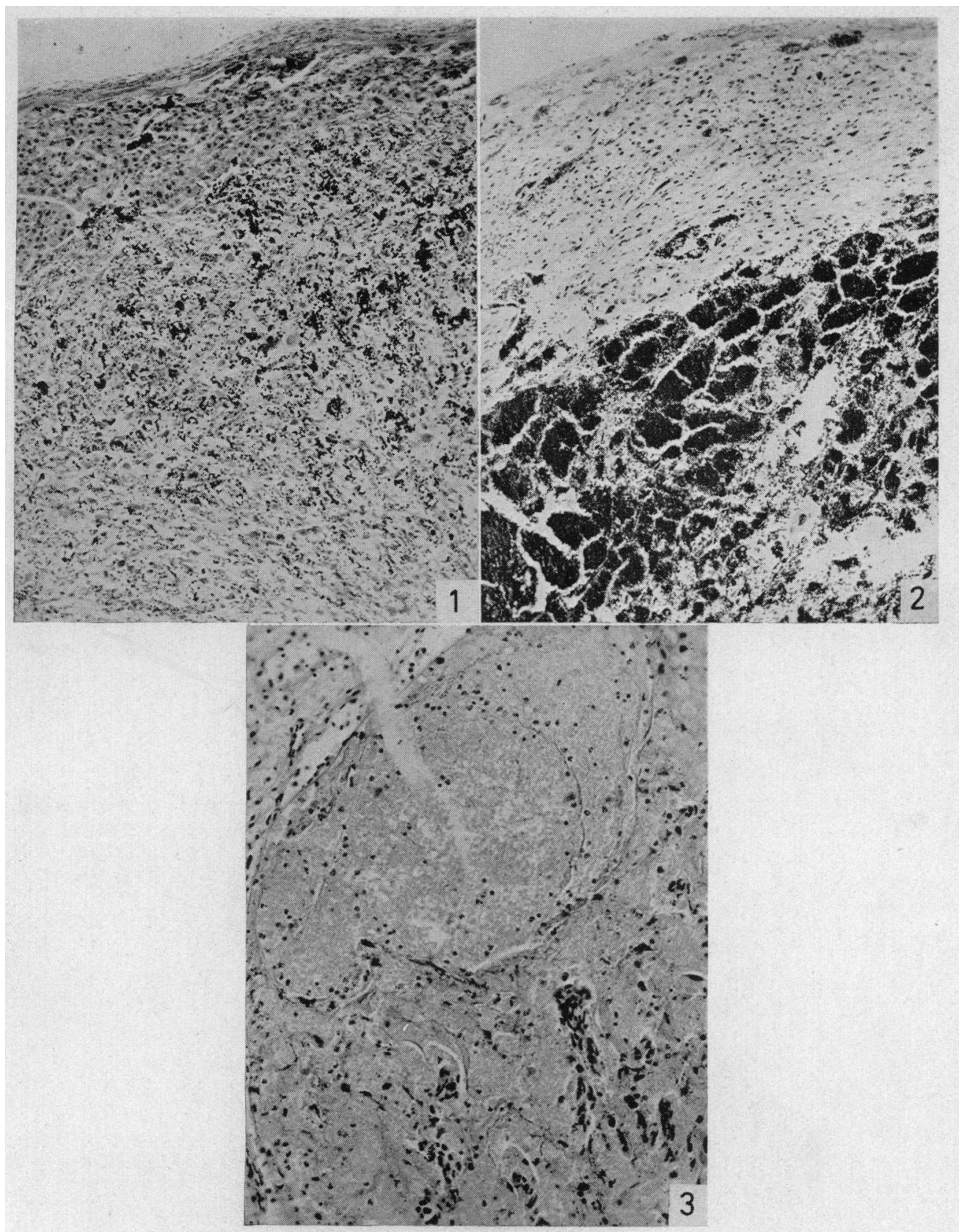

FIg. 1. Placenta of control rat. (Formol, Lepchne haemoglobin stain, haematoxylin, $\times 65$.)

FIg. 2. Placenta of a rat $12 \mathrm{hr}$ after subcutaneous injection of $0.04 \mathrm{~m}$-mole cadmium chloride per $\mathrm{kg}$ body wt. (Formol, Lepchne haemoglobin stain, haematoxylin, $\times 65$.) Note the striking difference between the changes in the pars foetalis and materna.

Fif. 3. Detail of the pars foetalis of rat placenta $24 \mathrm{hr}$ after cadmium injection (subcutancous, $0.04 \mathrm{~m}-\mathrm{mole} / \mathrm{kg}$ ). (Formol, haematoxylin and eosin, $\times 140$.)

(Facing p. 264) 


\section{REFERENCES}

Chiquorne, A. D. (1963) Studies on testicular necrosis induced by cadmium salts. Anat. Rec. 145, 216.

Mason, K. E., Brown, J. A. \& Nesbit, R. R. (1963) Gadmium-induced injury of the rat testis. Anat. Rec. 145, 257.

PAŘízex, J. (1596) Effect of cadmium salts on testicular tissue. Nature, Lond. 177, 1036.

PAḱízeK, J. (1957) The destructive effect of cadmium ion on testicular tissue and its prevention by zinc. 7. Endocrin. 15, 56.

Paर́ízek, J. (1960) Sterilization of the male by cadmium salts. F. Reprod. Fertil. 1, 294.

PAǩ́izek, J. (1963) Nêkteré metabolické problémy funkce gonad: varle jako cílový orgán. (Some metabolic aspects of gonadal function: testis as a target organ.) Cs. Fysiol. 12, 344.

PAŘizek, J. \& ZÁHoŘ, Z. (1956) Effect of cadmium salts on testicular tissue. Nature, Lond. 177, 1036. 